\title{
Performance comprehensive assessment method for intelligent transportation system of Shandong Province
}

\author{
Changying Chen ${ }^{1, a}$, Xiuhong Yang ${ }^{2, b}$ and Qi Feng ${ }^{1, c}$ \\ ${ }^{1}$ Information Institute, Shandong Academy of Sciences, Jinan 250014, China, \\ 2 Jinan Quancheng Middle School of Shandong Province, Jinan 250011, China, \\ a.chenchy@sdas.org, ${ }^{\text {b. }}$ redyangh@163.com, c.fengq@sdas.org
}

Keywords: intelligent transportation; assessment; Shandong Province

\begin{abstract}
Intelligent transportation system (ITS) is an effective method for solving existing traffic jam, traffic rules violation reduction and traffic low efficiency. We introduce the development of Shandong ITS construction in the latest three years, based on which we present a performance comprehensive assessment method for expressway and national and provincial highway (NPH) ITS construction. We comprehensively assess all quantitative parameters for Shandong all municipal ITS construction with the method. We further analyze the distribution of all municipal planned total investment, emphasizing all municipal distributions of current period total construction investment and construction fund and asset practical investment. All the analysis includes two situations: expressway and NPH. Practical data analysis shows that the difference of all municipal practical fund and asset investments is the main reason that cause the distinction of comprehensive performance assessment when investment difference is significant. The result can guide future ITS construction of Shandong and even China. It has also reference value for the assessment of other similar system construction.
\end{abstract}

\section{Introduction}

With the increase of Chinese population, vehicle sale volume increases year after year. However, the increase of highway volume lags behind that of vehicle volume greatly. Highway traffic pressure therefore increases day after day. In order to alleviate the pressure of Chinese traffic development, lower the rate of highway traffic accidents, and guarantee the freedom of highway traffic, Chinese government has made the construction of intelligent transportation system (ITS) to be the preferential solution to the issues [1-3]. The construction of Shandong provincial ITS has leaped into the front ranks of that of all over the country. Shandong government has invested large amount of fund, manpower and material sources into expressway, national and provincial highway (NPH) emphasized ITS construction during these years [4]. Shandong government made the policy of provincial unified arrangement and municipal independent construction. Intelligent transportation network of its expressway, NPH and county highway has begun to take shapes.

ITS construction is a huge phase achieved systematic engineering. How to maximally develop its performance is the eventual goal of system construction [5]. Its investment and construction are dominated by local governments. Economic and social benefits of its construction are the key points that governments learn investment benefit and then decide how to further invest its construction. Global research on ITS assessment can be summarized into that of economic benefit influence [6], that of its impact on environment [7], that of road traffic security [8], that of its technologies [9] and that of investment cost benefit [10]. However, the assessment for its total investment has not yet been involved.

In this paper, we originally present the approach and policy of ITS comprehensive performance assessment based on Shandong Provincial Highway Intelligent Transportation System Comprehensive Assessment Project. We further acquire the comprehensive performance assessment results for Shandong expressways and NPHs. Eventually, we perform data analysis for the results and further analyze the cause of investment performance discrepancy for all the municipal ITS 
construction based on the capital and asset plan of its construction, distribution differences of its current period construction capital and asset investment, and the distribution distinctions of its current period construction capital and asset practical arrangement rates.

\section{Performance assessment approach}

The goal of performance assessment for Shandong ITS is to guide inner-provincial ITS to be planned, constructed and operated by standards and quantified scientific assessment system based on the requirement of Shandong provincial expressway and NPH construction regulations. Moreover, orientation and quantified assessment effect should also be sufficiently developed.

Comprehensive index assessment system Comprehensive index assessment system of Shandong provincial intelligent transportation security system includes comprehensive assessment and standardized technological index sub-systems. We assess the comprehensive index assessment system from such six aspects as project plan, project construction, capital and asset management, guarantee conditions, technology standardization and performance assessment. These six indexes can be further separated into 6 first-grade indexes, 14 second-grade indexes, and 32 third-grade indexes. In this paper, we highlight performance assessment of ITS construction.

Comprehensive performance assessment is performed through quantifying individual assessment index, which is then added together. The total comprehensive performance assessment is reflected by a hundred-mark system—-the upper limit of assessment result is 100 marks.

\section{Assessment results}

3.1 Analysis of comprehensive assessment index Based on the above selected assessment indexes and quantified assessment approaches, we ask entire province distributed 16 municipal governments to respectively submit their own assessment documentations. We then respectively assess the performance of their expressway ITS and NPH ITS construction. Their assessment results are shown in Tables 1 and 2.

Table 1 Comprehensive performance assessment result of expressway ITS (\%)

\begin{tabular}{|c|c|c|c|c|c|c|c|c|c|c|c|c|c|c|c|}
\hline \multirow{2}{*}{\begin{tabular}{|c|}
$\begin{array}{c}\text { local } \\
\text { government } \\
\text { name }\end{array}$ \\
municipal \\
expressway \\
traffic \\
police \\
detachment
\end{tabular}} & \multirow{2}{*}{\begin{tabular}{|c}
$\begin{array}{c}\text { projec } \\
\text { t plan } \\
\text { (5) } \\
\text { total } \\
\text { plan }\end{array}$ \\
\end{tabular}} & \multicolumn{3}{|c|}{$\begin{array}{c}\text { project construction } \\
\text { (25) }\end{array}$} & \multicolumn{3}{|c|}{$\begin{array}{l}\text { capital and asset } \\
\text { management (20) }\end{array}$} & \multirow{2}{*}{$\begin{array}{c}\begin{array}{c}\text { guarantee } \\
\text { condition } \\
(5)\end{array} \\
\begin{array}{c}\text { operation } \\
\text { and } \\
\text { maintenanc } \\
\text { e guarantee }\end{array}\end{array}$} & \multicolumn{4}{|c|}{$\begin{array}{c}\text { expressway ITS standardization index } \\
\text { (25) }\end{array}$} & \multicolumn{2}{|c|}{$\begin{array}{l}\text { performance } \\
\text { assessment (20) }\end{array}$} & \multirow[t]{2}{*}{\begin{tabular}{|c|} 
assess \\
ment \\
result
\end{tabular}} \\
\hline & & $\begin{array}{l}\text { regime } \\
\text { build }\end{array}$ & $\begin{array}{l}\text { manage } \\
\text { process }\end{array}$ & $\begin{array}{l}\text { projec } \\
\mathrm{t} \\
\text { check } \\
\text { and } \\
\text { accept }\end{array}$ & $\begin{array}{c}\text { arrang } \\
\mathrm{e} \\
\text { capital }\end{array}$ & \begin{tabular}{|l|} 
capita \\
I super \\
vision
\end{tabular} & $\begin{array}{c}\text { manage } \\
\text { asset }\end{array}$ & & $\begin{array}{l}\text { networkin } \\
\text { g butt joint }\end{array}$ & $\begin{array}{c}\text { function } \\
\text { complet } \\
\mathrm{e}\end{array}$ & \begin{tabular}{|c|} 
data \\
standar \\
d
\end{tabular} & $\begin{array}{l}\text { standar } \\
\text { d setting }\end{array}$ & $\begin{array}{c}\text { operation } \\
\text { performanc } \\
\text { e }\end{array}$ & $\begin{array}{c}\text { social } \\
\text { benefi } \\
\mathrm{t}\end{array}$ & \\
\hline & 5 & 8 & 10 & 7 & 10 & 7 & 3 & 5 & 5 & 10 & 5 & 5 & 10 & 10 & 100 \\
\hline Zibo & 3.5 & 6.0 & 5.6 & 5.0 & 8.0 & 4.0 & 2.0 & 3.5 & 5.0 & \multicolumn{3}{|c|}{19.6} & 8.0 & 8.0 & 78.2 \\
\hline Yantai & 3.0 & 4.5 & 6.0 & 4.0 & 8.0 & 4.0 & 3.0 & 2.7 & 5.0 & \multicolumn{3}{|c|}{18.9} & 5.0 & 5.8 & 69.9 \\
\hline Weihai & 3.6 & 6.0 & 5.0 & 5.0 & 8.0 & 4.0 & 3.0 & 3.0 & 5.0 & \multicolumn{3}{|c|}{9.2} & 8.0 & 8.0 & 67.8 \\
\hline Laiwu & 4 & 7.88 & 5.56 & 4.6 & 8 & 3 & 2 & 3.4 & 5 & \multicolumn{3}{|c|}{14.2} & 6 & 7 & 70.6 \\
\hline Linyi & 4 & 7 & 8 & 3.9 & 10 & 5 & 3 & 4 & 5 & \multicolumn{3}{|c|}{19.9} & 8 & 7 & 84.8 \\
\hline Dezhou & 4.5 & 8 & 9 & 6.1 & 10 & 7 & 3 & 4.7 & 5 & \multicolumn{3}{|c|}{20} & 9 & 8 & 94.3 \\
\hline Liaocheng & 4 & 6.2 & 7 & 6 & 7 & 3 & 3 & 4.2 & 5 & \multicolumn{3}{|c|}{12.4} & 9 & 9 & 75.8 \\
\hline Hezhe & 4.5 & 7.3 & 4.96 & 4.6 & 8 & 3 & 3 & 3.18 & 5 & \multicolumn{3}{|c|}{14.6} & 7 & 7.6 & 72.7 \\
\hline
\end{tabular}


Table 2 Comprehensive performance assessment result of NPH ITS (\%)

\begin{tabular}{|c|c|c|c|c|c|c|c|c|c|c|c|c|c|c|c|}
\hline $\begin{array}{c}\text { local } \\
\text { government }\end{array}$ & $\begin{array}{l}\text { project } \\
\text { plan (5) }\end{array}$ & proje & $\begin{array}{l}\text { constr } \\
(25)\end{array}$ & uction & $\begin{array}{l}\text { capit } \\
\text { mana }\end{array}$ & $\begin{array}{l}\text { tal and } \\
\text { agemen }\end{array}$ & $\begin{array}{l}\text { asset } \\
(20)\end{array}$ & $\begin{array}{c}\text { guarantee } \\
\text { condition (5) }\end{array}$ & NPH ITS & standardi & zation ind & lex (25) & $\begin{array}{r}\text { perform } \\
\text { assessmen }\end{array}$ & $\begin{array}{l}\text { ance } \\
\text { t (20) }\end{array}$ & $\begin{array}{c}\text { Assess } \\
\text { ment }\end{array}$ \\
\hline \begin{tabular}{|c} 
municipal \\
traffic police \\
detachment
\end{tabular} & $\begin{array}{l}\text { total } \\
\text { plan }\end{array}$ & $\begin{array}{c}\text { regime } \\
\text { build }\end{array}$ & \begin{tabular}{|c|} 
manag \\
$\mathrm{e}$ \\
process
\end{tabular} & $\begin{array}{l}\text { project } \\
\text { check } \\
\text { and } \\
\text { accept }\end{array}$ & \begin{tabular}{|c|} 
arrange \\
capital
\end{tabular} & \begin{tabular}{|c} 
capital \\
super \\
vision
\end{tabular} & $\begin{array}{l}\text { manag } \\
\text { easset }\end{array}$ & $\begin{array}{c}\text { operation and } \\
\text { maintenance } \\
\text { guarantee }\end{array}$ & $\begin{array}{l}\text { networking } \\
\text { butt joint }\end{array}$ & \begin{tabular}{|l|} 
function \\
complete
\end{tabular} & $\begin{array}{c}\text { data } \\
\text { standard }\end{array}$ & $\begin{array}{c}\text { standard } \\
\text { setting }\end{array}$ & $\begin{array}{c}\text { operation } \\
\text { performance }\end{array}$ & $\begin{array}{l}\text { social } \\
\text { benefit }\end{array}$ & \\
\hline & 5 & 8 & 10 & 7 & 10 & 7 & 3 & 5 & 5 & 10 & 5 & 5 & 10 & 10 & 100 \\
\hline Jinan & 3.5 & 6.8 & 7.6 & 5.3 & 8.8 & 5.5 & 2.6 & 3.5 & 5 & & 16.4 & & 8.2 & 8.4 & 81.6 \\
\hline Zibo & 4.5 & 8 & 8.9 & 6.4 & 10 & 7 & 3 & 4.5 & 5 & & 20 & & 9 & 9 & 95.3 \\
\hline Zaozhuang & 3.5 & 7.1 & 8.7 & 5.1 & 10 & 6 & 3 & 4 & 5 & & 19.5 & & 8.9 & 9 & 89.8 \\
\hline Dongying & 4.5 & 7.6 & 5.3 & 4 & 8.3 & 4.3 & 1.3 & 2.2 & 5 & & 18 & & 5.95 & 6.5 & 72.95 \\
\hline Yantai & 3.02 & 5.97 & 6.22 & 4.56 & 8.27 & 4.91 & 2.09 & 3.67 & 5 & & 17.15 & & 7.41 & 7.46 & 75.73 \\
\hline Weifang & 3.62 & 6 & 6.5 & 5.53 & 7.6 & 5.3 & 2.03 & 3.58 & 5 & & 11.4 & & 6.87 & 7.1 & 70.53 \\
\hline Jining & 3.22 & 6.8 & 6.96 & 4.92 & 9.2 & 5 & 1 & 4 & 5 & & 14.74 & & 8.34 & 8.44 & 77.62 \\
\hline Taian & 2.86 & 6.76 & 7.35 & 6.68 & 9.2 & 4.4 & 1.8 & 3.37 & 5 & & 18.9 & & 7.6 & 7.4 & 81.32 \\
\hline Weihai & 4.5 & 6.75 & 7.88 & 5.4 & 8.75 & 5.75 & 2.5 & 4.25 & 5 & & 19.1 & & 7.75 & 7.5 & 85.13 \\
\hline Rizhao & 2.93 & 5.3 & 5.23 & 5.3 & 8.67 & 3.6 & 2.3 & 2.67 & 5 & & 14.87 & & 7.67 & 8 & 71.54 \\
\hline Linyi & 3.36 & 6.65 & 5.94 & 4.02 & 8.94 & 5.2 & 2.29 & 3.98 & 5 & & 18.5 & & 6.89 & 7.06 & 77.83 \\
\hline Dezhou & 3.31 & 6.12 & 7.084 .1 & 24.72 & 9.04 & 44.7 & 24.72 & $\begin{array}{ll}3.62 & 9 \\
\end{array}$ & 5 & 4.7 & 18.22 & & 3.627 .26 & 7569 & 79.08 \\
\hline \begin{tabular}{|l|} 
Liaocheng \\
\end{tabular} & 4 & 6.98 & 7.9 & 6.5 & 8.75 & 4.25 & 2.5 & 3.93 & 5 & & 17.2 & & 7.85 & 8.45 & 83.31 \\
\hline Binzhou & 3.38 & 6.64 & 6.23 & 5.19 & 7.8 & 5 & 2 & 4.35 & 5 & & 18.72 & & 6.88 & 7.4 & 78.59 \\
\hline Hezhe & 4.5 & 7.5 & 5.2 & 6.1 & 8 & 6.6 & 3 & 3.78 & 5 & & 13.6 & & 8.8 & 8.2 & 80.28 \\
\hline
\end{tabular}

From these two tables, we discover that the discrepancy of ITS construction of different municipalities is quite significant. Among the 16 municipalities, only half of them invest and construct their own expressway ITS. Moreover, performance differences are also obvious for the constructed expressway ITS, among which Dezhou has the best construction effect (comprehensive assessment result of $94.3 \%$ ), while the construction effect of Weihai is worst (only comprehensive assessment result of $67.8 \%$ ). The distinction of $26.5 \%$ exists. However, construction situation of NPH ITS of all the municipalities is slightly better than that of their expressway ITS. The construction situation of Zibo NPH ITS is the best, whose comprehensive assessment result is 95.3\%, while that of Weifang NPH ITS is the worst, whose assessment result is 70.53\%. Difference of assessment results attains $24.77 \%$.

Based on our above assessment results, we further analyze the capital and asset investment situation of ITS construction for all municipalities because the distinction of their ITS performance is largely caused by the difference of their capital and asset investment.

3.2 Analysis of capital and asset investment ITS construction of Shandong province was launched in recent years. Shandong Provincial Public Security Department highlights ITS construction from 2013 to 2015, so we predominantly investigate total investment, current period total investment and current period construction capital arrangement, which will be respectively analyzed in below three sections.

3.2.1 Analysis of total investment distribution ITS construction of Shandong entire province is divided into two independent parts - expressway and NPH ITS construction. Thus, we divide the total investment of all municipal governments in the recent three years into expressway ITS three-year total investment and NPH ITS three-year total investment to be analyzed. Expressway ITS total investment distribution in the recent three years is shown in Fig.1, where we can discover that construction investment of Yantai and Dezhou expressway ITS is the highest, while that of Laiwu expressway ITS is the lowest (only 16 million yuan (RMB)). 


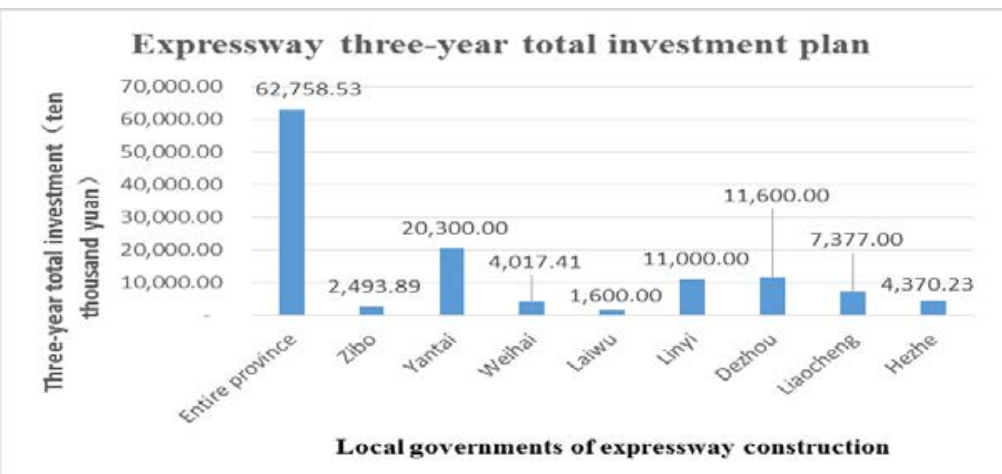

Fig.1 Distribution graph of entire province expressway ITS construction investment Investment distribution of entire province NPH ITS construction in the recent three years is shown in Fig.2. From the figure, we can discover that for the NPH ITS construction, three-year total planned investment of Jinan and Yantai are the highest, while that of Rizhao is the lowest, only 12.7 million yuan (RMB).

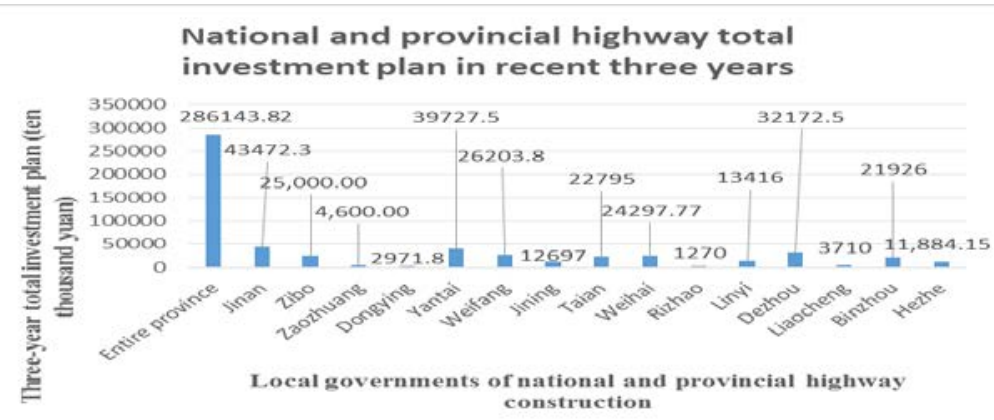

Fig.2 Distribution graph of NPH ITS construction investment

3.2.2 Analysis of current period total investment Shandong ITS construction includes three periods, we only investigate and analyze total planned investment of every municipal government in the first period (from March 2014 to March 2015). We still divide ITS construction investment of entire province into expressway ITS current period total investment and NPH ITS current period total investment to be analyzed. Total planned investment distribution of expressway ITS construction of all municipal governments is shown in Table 3, while that of NPH ITS construction is shown in Table 4. From Table 3, we discover that current period total planned investment on Dezhou expressway ITS is the highest, whose proportion to entire province attains $62.56 \%$; that on Linyi expressway ITS is next highest, whose proportion to entire province reaches $31.57 \%$. However, that on Liaocheng expressway ITS is the lowest, whose proportion to entire province is only $0.24 \%$. For NPH ITS construction, from Table 4, we find that current period total planned investment on Dezhou NPH is the highest, which accounts for $19.27 \%$ of provincial total investment. That on Yantai NPH is next highest, which accounts for $17.43 \%$ of provincial total investment. While that on Rizhao NPH is the lowest, only $0.39 \%$ of provincial total investment.

Table 3 Distribution of current period total planned investment of entire province expressway ITS construction

\begin{tabular}{|c|c|c|}
\hline Local government name & $\begin{array}{c}\text { Current period total planned investment on expressway ITS (Ten } \\
\text { thousand yuan (RMB)) }\end{array}$ & Proportion (\%) \\
\hline Dezhou & $10,100.00$ & 62.56 \\
\hline Linyi & $5,096.00$ & 31.57 \\
\hline Yantai & 292.00 & 1.81 \\
\hline Hezhe & 235.81 & 1.46 \\
\hline Zibo & 188.89 & 1.17 \\
\hline Laiwu & 98.00 & 0.61 \\
\hline Weihai & 95.59 & 0.59 \\
\hline Liaocheng & 38.00 & 0.24 \\
\hline
\end{tabular}

Table 4 Distribution of current period total planned investment of NPH ITS construction 


\begin{tabular}{|c|c|c|}
\hline Local government name & $\begin{array}{c}\text { Current period total planned investment on NPH ITS (Ten } \\
\text { thousand yuan (RMB)) }\end{array}$ & Proportion (\%) \\
\hline Dezhou & 18691.79 & 19.27 \\
\hline Yantai & 16903.92 & 17.43 \\
\hline Jinan & 12469.6 & 12.85 \\
\hline Weihai & 11290.18 & 11.64 \\
\hline Zibo & $7,905.00$ & 8.15 \\
\hline Taian & 7096 & 7.32 \\
\hline Binzhou & 6421.76 & 6.62 \\
\hline Linyi & 5365.02 & 5.53 \\
\hline Jining & 3470 & 3.58 \\
\hline Weifang & 3158.1 & 3.26 \\
\hline Zaozhuang & $1,405.00$ & 1.45 \\
\hline Dongying & 1008.6 & 1.04 \\
\hline Hezhe & 784.03 & 0.81 \\
\hline Liaocheng & 647.4 & 0.67 \\
\hline Rizhao & 385.96 & 0.39 \\
\hline
\end{tabular}

3.2.3 Analysis of current period construction capital arrangement Performance of ITS construction is associated not only with total investment of capital and asset plan, but also with practical arrangement of construction capital. Therefore, only analysis of total planned investment of ITS construction is not enough. We then also analyze practical arrangement distribution of current period ITS construction capital for all municipal governments, which is also divided into two cases: practical arrangement of expressway and NPH ITS construction capital, to be analyzed. Practical arrangement distribution of current period expressway ITS construction capital is shown in Table 5, and that of current period NPH ITS construction capital is shown in Table 6. From Table 5, we discover that practical arrangement of Dezhou current period expressway ITS construction capital is the best, which accounts for $62.56 \%$ of entire province practical capital arrangement. That of Linyi expressway ITS current period construction capital is next best, which accounts for $31.57 \%$ of entire province practical capital arrangement. However, that of Liaocheng expressway current period ITS construction capital is the worst, which accounts for only $0.24 \%$ of entire province practical capital arrangement. On the other hand, from Table 6, we find that practical arrangement of Yantai NPH ITS current period construction capital is the best, which accounts for $19.06 \%$ of entire province practical total NPH construction capital arrangement.

Table 5 Practical arrangement distribution of current period construction capital of entire province expressway ITS

\begin{tabular}{|c|c|c|}
\hline Local government name & $\begin{array}{c}\text { Practical arrangement of current period expressway ITS construction } \\
\text { capital (Ten thousand yuan (RMB)) }\end{array}$ & Proportion (\%) \\
\hline Dezhou & $10,100.00$ & 62.56 \\
\hline Linyi & $5,096.00$ & 31.57 \\
\hline Yantai & 292.00 & 1.81 \\
\hline Hezhe & 235.81 & 1.46 \\
\hline Zibo & 188.89 & 1.17 \\
\hline Laiwu & 98.00 & 0.61 \\
\hline Weihai & 95.59 & 0.59 \\
\hline Liaocheng & 38.00 & 0.24 \\
\hline
\end{tabular}


Table 6 Practical arrangement distribution of current period construction capital of entire province NPH ITS

\begin{tabular}{|c|c|c|}
\hline $\begin{array}{c}\text { Local government } \\
\text { name }\end{array}$ & $\begin{array}{c}\text { Practical arrangement of current period NPH ITS construction capital (Ten } \\
\text { thousand yuan (RMB) }\end{array}$ & Proportion (\%) \\
\hline Yantai & 18097.52 & 19.06 \\
\hline Dezhou & 16422.94 & 17.3 \\
\hline Jinan & 11959 & 12.6 \\
\hline Weihai & 11290.18 & 11.89 \\
\hline Zibo & $7,905.00$ & 8.33 \\
\hline Taian & 7096 & 7.48 \\
\hline Binzhou & 6045.32 & 6.37 \\
\hline Linyi & 5323.02 & 5.61 \\
\hline Jining & 3470 & 3.66 \\
\hline Weifang & 3158.1 & 3.33 \\
\hline Zaozhuang & $1,405.00$ & 1.48 \\
\hline Dongying & 935.6 & 0.99 \\
\hline Hezhe & 764.80 & 0.81 \\
\hline Liaocheng & 647.4 & 0.68 \\
\hline Rizhao & 406 & 0.43 \\
\hline
\end{tabular}

That of Dezhou NPH ITS current period construction capital is next best, which accounts for $17.3 \%$ of entire province practical total NPH construction capital arrangement. However, that of Rizhao NPH ITS current period construction capital is the lowest, only $0.43 \%$ of entire province current period total NPH ITS construction investment.

\section{Conclusion}

Analytical results show that capital and asset investment on ITS construction has significant impact on ITS comprehensive performance when the differences of capital and asset investment are much greater. However, ITS standardization index, normality of project construction and management, system operation performance and social benefit will have large effect on ITS comprehensive performance when the differences of capital and asset investment are not too much. Our comprehensive assessment on entire province ITS construction objectively reflects the benefits of Shandong ITS construction. This demonstrates that our presented approach is feasible. This analytical results will guide future ITS construction in Shandong province and even the whole country (China). It will also have reference value on the assessment of other similar system construction.

\section{Acknowledgements}

This work was financially supported by the China National Natural Science Foundation (61401256).

\section{References}

[1] Minzhi Chen, Yongkai Hu: Studies on construction and operation mode of intelligent transportation systems. Applied Mechanics and Materials. Vol. 587-589 (2014), p. 1780-1784 [2] Yongkai Hu, Wei Wang, Haiyan Gu: Research on construction and operation mode of intelligent transportation systems. Applied Mechanics and Materials. Vol. 209-211 (2012), p. 683-687

[3] Fengqi Zhou, Jun Shen: Deploying an intelligent transportation system in Chongming county, Shanghai. Journal of Urban Technology, Vol. 17-3 (2010), p. 39-51

[4] Zhang Xiong, Hao Sheng, Wenge Rong, etc.: Intelligent transportation systems for smart cities: a progress review. Science China (Information Sciences). Vol. 12-12 (2012), p. 2908-2914 
[5] Fengping Zhan, Wei Wang, Jian Zhang, etc.: Research on the construction mechanisms for intelligent transportation systems in foreign countries. Advanced Materials Research. Vol. 594-597 (2012), p. 3024-3028

[6] JIN Z C, WU J P, McDonald M: Socio-Economic Impact Assessment of Intelligent Transport Systems. Tsinghua Science and Technology. Vol. 11-3, (2006), p. 339-350

[7] CHEN C, XU Y, SHANG J C: Alternatives of strategic environmental assessment of road traffic development planning - Case of Changchun City, China. Chinese Geographical Science. Vol. 19-1 (2009), p. 25-36

[8] MINDERHOUD M M, BOVY P H L: Extended time-to-collision measures for road traffic safety assessment. Accident Analysis\& Prevention. Vol. 33-1 (2001), p. 89-97

[9] YUKO J N, JOHN C F: Performance assessment of intelligent transportation systems using data envelopment analysis. Research in Transportation Economics. Vol. 8-1 (2004), p. 181-197

[10] ALAN S: The application and limitations of cost-benefit assessment (CBA) for intelligent transport systems. Research in Transportation Economics. Vol. 8-1 (2004), p. 91-111 